\title{
IMPLIKASI HUKUM PANDEMI COVID-19 TERHADAP TRANSAKSI AKAD BAI'AS-SALAM (PRE ORDER) DALAM TRANSAKSI DROPSHIP
}

Rahmadi Indra Tektona, Risqullah Cahyanan Putra; Fakultas Hukum Universitas Jember; Jln. Kalimantan 37, Jember 68121; E-mail: rahmadiindra@unej.ac.id

\begin{abstract}
Abstrak
Coronavirus Disease-19 atau yang lebih dikenal dengan istilah COVID-19 merupakan virus yang muncul pada akhir tahun 2019. Virus tersebut mempengaruhi hampir seluruh sektor kehidupan manusia di berbagai negara pada tahun 2020. Penyebarannya yang sangat cepat dapat menimbulkan kerugian bagi sebuah negara. Beberapa sektor akan terkena dampak dari adanya virus ini seperti sektor ekonomi, pariwisata, dan budaya. Indonesia juga dipastikan terkena dampaknya. Salah satu sektor yang dipastikan adalah sektor perekonomian, yang merujuk pada ekonomi syariah yang dalam hal jual beli akad as-salam (pre order). Dampak negatif yang ditimbulkan dari penyebaran Coronavirus Disease-19 ini ialah adanya keterlambatan pengiriman barang. Terlebih setelah pemerintah memutuskan untuk mengeluarkan himbauan terkait physical distancing dan WFH atau Work From Home, masyarakat semakin giat melakukan kegiatan jual beli secara online. Hal tersebut dilakukan karena masyarakat merasa perlu untuk memenuhi kebutuhannya sehari-hari dengan demikian hal tersebut dapat menguntungkan beberapa pihak. Tetapi, perlu pula memperhatikan kepastian terhadap melakukan jual beli online secara pre order agar tidak menimbulkan perselisihan yang beresiko terjadinya penipuan.
\end{abstract}

Kata Kunci: Coronavirus Disease-19, Jual Beli, Akad As-Salam (Pre Order), Implikasi Hukum

\begin{abstract}
Coronavirus Disease-19 or better known as COVID-19 is a virus that emerged at the end of 2019. The virus affects almost all sectors of human life in various countries by 2020. The spread that is extremely rapid can cause losses to a countries. Several sectors will be affected by this virus, such as the economy, tourism and culture. Indonesia is also confirmed to be affected. One of the sectors that is confirmed is the economic sector, which refers to the Islamic economy in terms of buying and selling the as-salam contract (pre-order). The negative impact arising from the spread of Coronavirus Disease-19 is the delay in the delivery of goods. Especially after the government decided to issue an appeal related to physical distancing and WFH or Work From Home, people are increasingly active in online buying and selling activities. It is because people need to meet their daily needs so that it can benefit several parties. However, it is also necessary to pay attention to the certainty of buying and selling online by pre-order so as not to cause disputes that are at risk of fraud.
\end{abstract}

Keywords: Coronavirus Disease-19, Sale and Purchase, Akad As-Salam (Pre Order), Legal Implications 


\section{PENDAHULUAN}

\section{Latar Belakang}

Awal tahun 2020, dunia digemparkan dengan munculnya laporan kasus penyakit yang saat ini dikenal dengan nama Coronavirus Disease-19 (Covid-19). Wuhan sebagai ibukota dari Provinsi Hubei yang terletak di China Tengah menjadi tempat pertama terdeteksinya Coronavirus Disease-19 ini. Permulaan kasus ini terjadi pada awal Desember 2019, yang mana seseorang yang didiagnosa penyakit pneumonia yang tidak biasa. Pasien dengan diagnosa yang sama dan dari kota yang sama terus bertambah, sehingga kabar tersebut sampai pada kantor regional organisasi kesehatan dunia (WHO) yang berada di Beijing. Identifikasi dengan analisis metagenomik dilakukan untuk mengetahui virus corona baru sebagai sebuah etiologi potensial, yang mana virus ini tergolong dalam superdomain biota, kingdom virus dan familia coronaviridae. ${ }^{1}$

Virus ini dinyatakan oleh WHO sebagai kejadian pandemik yang berarti merupakan penyakit yang harus diwaspadai dan perlu diberi perhatian yang khusus. Penyebaran virus ini menular dari manusia ke manusia lainnya melalui droplet akibat batuk ataupun bersin. Covid-19 menyebar dengan cepat dan hampir menyebar ke seluruh belahan dunia, bahkan sejauh ini pada akhir bulan Mei 2020 tercatat 215 negara melaporkan adanya kasus Covid-19dengan jumlah total kasus sebesar 5.925 .660 orang positif, 362.555 orang meninggal, dan 2.593 .676 orang dinyatakan sembuh dari virus ini. ${ }^{2}$ Indonesia termasuk salah satu negara yang melaporkan adanya kasus Coronavirus Disease-19. Hal tersebut tentunya menimbulkan dampak bagi suatu negara dalam berbagai bidang seperti perekonomian, sosial, budaya, pariwisata, dan pastinya kesehatan.

Berdasarkan data yang dilansir dari Worldometers, diketahui bahwa jumlah penduduk Indonesia adalah 269,1 juta orang. Tentunya jumlah populasi tersebut tidaklah sedikit, terlebih lagi Indonesia merupakan negara kepulauan yang mana penduduknya tersebar pada pulau-pulau yang mencapai belasan ribu. Indonesia termasuk sebagai negara yang dipastikan akan terkena dampak dari Covid-19. Dengan mewabahnya Covid-19 di Indonesia maka akan berpengaruh dalam bidang ekonomi. Direktur Pelaksana Bank Dunia Mari Elka Pangestu memberikan perkiraan terkait pertumbuhan ekonomi Indonesia yang bisa melemah di bawah 5\% pada kuartal I tahun 2020. Mari Elka mengatakan bahwa menurunnya produk domestik bruto China yang mencapai hingga $1 \%$ poin akan mengoreksi sebesar $0,3 \%$ poin pertumbuhan ekonomi Indonesia. Hal ini dapat terjadi sebab Indonesia merupakan salah satu mitra dagang China, dan sebaliknya China sebagai penyumbang wisatawan terbesar di Indonesia. ${ }^{3}$ Pengaruh yang ditimbulkan dalam perekonomian dari sisi perdagangan, investasi hingga pariwisata.

Penyebaran virus Corona juga menyebabkan penurunan kegiatan produksi di China, yang mana China merupakan negara pusat produksi barang dunia. Indonesia juga

1 MLE Parwanto. (2020). Virus Corona (2019-NCOV) Penyebab Covid-19, Jurnal Biomedika dan Kesehatan, Vol. 3, Nomor 1, h. 1.

2 Worldometer. Covid-19 Coronavirus Pandemic. https://www.worldometers.info/coronavirus/ (Diakses pada 2 Juni 2020).

${ }^{3}$ Chairul Iksan Burhanuddin, dkk. (2020). Ancaman Krisis Ekonomi Global dari Dampak Penyebaran Virus Corona (Covid-19), Jurnal Akuntansi, Vol. 17, Nomor 1, h. 97. 
sebagai salah satu negara yang sangat bergantung dengan bahan baku dari China, terutama bahan baku tekstil, plastik, furnitur, komputer, dan part elektronik. Hal ini membuat Indonesia harus mencari importir dari negara lain selain China agar tidak bergantung hanya kepada China. Virus ini juga memberikan dampak pada investasi. Masyarakat akan lebih berhati-hati ketika membeli barang ataupun berinvestasi. Supply chain yang tidak jelas dan asumsi pasar yang berubah memberi pengaruh pada proyeksi pasar yang dapat menyebabkan investor menunda investasi. ${ }^{4}$

Sektor perdagangan sangat terpengaruh akibat adanya Covid-19 dan berdampak negatif terhadap kualitas dan kuantitas jual beli. Salah satu dampak yang akan penulis bahas disini ialah pada keterlambatan pengiriman barang dalam jual beli akad as-salam (pre order). Dengan mewabahnya Covid-19 kegiatan jual beli masyarakat secara offline atau tatap muka langsung dengan pembelinya juga mengalami penurunan. Hal tersebut disebabkan karena adanya perintah dari pemerintah untuk tetap berada di dalam rumah dan menjaga jarak untuk mencegah adanya penyebaran, sehingga rantai penyebaran Covid-19 dapat terputus. Masyarakat keluar dari rumahnya sesekali hanya untuk berbelanja offline memenuhi kebutuhan sehari-hari.

Dengan keberadaan masyarakat di rumah membuat mereka melakukan aktivitas yang dapat dilakukan di rumah seperti belanja kebutuhan sehari-hari secara daring (online) yang hanya menunggu barang sampai dirumah dengan cara pre order. Hal tersebut termasuk dalam kegiatan perjanjian jual beli online menggunakan sistem akad salam. Jual beli salam adalah "jual beli pesanan", yakni pembeli membeli barang berdasarkan kriteria tertentu dengan cara melakukan pembayaran terlebih dahulu dan barang yang dibeli akan diterimanya pada waktu tertentu setelah pembayaran. ${ }^{5}$

\section{Rumusan Masalah}

Dari latar belakang yang di atas, penulis menemukan permasalahan yakni bagaimanakah implikasi hukum covid-19 terhadap transaksi akad bai' as-salam (pre-order), dengan tujuan penulisan untuk mengetahui implikasi covid-19 terhadap transaksi sistem akad bai' as-salam (pre-order) sehingga dapat menambah referensi penulisan artikel dalam bidang ekonomi syariah.

\section{METODE PENELITIAN}

Tipe penelitian yang penulis gunakan untuk mengkaji permasalahan dalam artikel ini yaitu penelitian normatif dengan melakukan pendekatan perundangan-undangan, pendekatan konseptual, serta pendekatan kasus. Penulis menggunakan metode penelitian yuridis normatif dengan cara meneliti bahan pustaka atau data sekunder dan melakukan penelusuran terhadap peraturan dan literatur yang berkaitan dengan permasalahan yang diteliti.

Adapun dalam menjawab permasalahan yang diteliti, penulis menggunakan studi kepustakaan dari 3 (tiga) bahan hukum, yaitu:

\footnotetext{
${ }^{4}$ Silpa Hanoatubun. (2020). Dampak Covid-19 terhadap Perekonomian Indonesia, Journal Of Education, Psychology, And Counseling, Vol. 2, Nomor 1, h. 147.

${ }^{5}$ Rozalinda. (2016). Fiqih Ekonomi Syariah. Jakarta: Raja Grafindo Persada, h. 94.
} 
1. Bahan hukum primer, yang terdiri dari Al-Qur'an, Hadits, dan Ijma

2. Bahan hukum sekunder, yang merupakan literatur hukum seperti buku, jurnal, dan skripsi hukum yang berkaitan dengan hukum islam, ekonomi syariah

3. Bahan hukum tersier, yang merupakan penjelasan tambahan bahan hukum primer dan sekunder berupa penelusuran-penelusuran di internet.

\section{PEMBAHASAN}

\section{Pengertian Transaksi Akad Bai' As-Salam (Pre-order)}

Pada dasarnya jual beli secara harfiah terdiri dari "jual" dan "beli". Keduanya memiliki arti yang bertolak belakang satu sama lain. Kata "jual" menjelaskan adanya perbuatan menjual, sedangkan kata "beli" menjelaskan adanya perbuatan membeli. ${ }^{6}$ Jual beli secara etimologi adalah proses tukar-menukar antara barang dengan barang. Jual beli atau bai' dalam istilah fiqih merupakan kata yang memiliki makna ganda, makna dari bai' bersebrangan sama halnya dengan kata syira' (pembeli). Jual beli secara terminologi menurut pendapat ulama Imam Abu Hanafi adalah tukar menukar maal dengan maal (dapat berupa barang ataupun harta) atau tukar menukar barang yang bernilai dengan semacamnya yang dilakukan dengan cara tertentu, sah dan khusus, yakni ijab-kabul atau mu'aathaa' (tanpa ijab-kabul). ${ }^{7}$

Ulama Malikiyah membedakan pengertian jual beli menjadi dua macam, yaitu jual beli secara umum dan jual beli secara khusus. Jual beli secara umum ialah jual beli yang perikatan tukar menukarnya tidak dilihat dari kemanfaatan dan kenikmatan. Sedangkan jual beli secara khusus ialah jual beli yang perikatan tukar menukarnya tidak dilihat dari daya tarik manfaat ataupun kelezatannya, namun dilihat dari wujud barang maupun sifat-sifat barang tersebut, merupakan benda yang dapat direalisaskian, dalam hal ini bukan bukan emas, perak, utang (baik barang itu ada dihadapan pembeli maupun tidak). ${ }^{8}$

Menurut pendapat Malikiyah, Syafi'iyah dan Hanabilah jual beli (al-bay') merupakan tukar menukar antara harta dengan harta dalam hal pemindahan milik dan kepemilikan. ${ }^{9}$ Jual beli pesanan, bai' as-salam, dan bai' as-salaf memiliki arti yang sama. Penduduk Hijaz (Madinah) menggunakan kata salam, sedangkan penduduk Irak menggunakan salaf. Salam atau salaf secara bahasa bermakana: "Menyegerakan modal dan mengemudiankan barang". ${ }^{10}$ Sayyid Sabiq menerangkan as-salam adalah penjualan sesuatu yang memiliki kriteria tertentu (yang masih berada) dalam tanggungan yang pembayaran dilakukan

\footnotetext{
${ }^{6}$ Chairuman Pasaribu Dan Suhrawardi K. Lubis. (2016). Hukum Perjanjian dalam Islam. Jakarta: Sinar Grafika, h. 18.

7 Wahbah Al-Zuhaili. (2015). Fiqih Islam Wa Adillatuhu. Jilid V. Jakarta: Gema Insan, h. 27.

8 Abdul Haris Simal. (2019). Pelaksanaan Jual Beli dengan Menggunakan Akad As-Salam Ditinjau dari Prinsip Tabadul Al-Manafi. Jurnal Cahkim, Vol. XV, No. 1, h. 111.

${ }^{9}$ Mardani. (2017). Fiqih Ekonomi Syariah: Fiqih Muamalah. Jakarta: Kencana Prenada Media Group, h. 101.

${ }^{10}$ Shobirin. (2015). Jual Beli dalam Pandangan Islam. Jurnal Bisnis dan Manajemen Islam. Vol. 3, No. 2, h. 240 .
} 
dengan segera atau disegerakan.11 Salam menurut ulama Syafi'iyah dan Hanabilah merupakan akad atas barang pesanan yang memiliki spesifikasi tertentu yang penyerahannya ditangguhkan sampai pada waktu tertentu, dan pembayaran dilakukan di majelis akad secara tunai. Ulama Malikiyyah menjelaskan salam merupakan akad jual beli dimana modal (pembayaran) dilakukan di awal dan secara tunai, dan objek pesanan akan diserahkan di kemudian dengan jangka waktu tertentu. ${ }^{12}$

Penjual ketika melakukan proses akad salam hendaknya menyebutkan identitas yang melekat pada objek jual beli (menyangkut kualitas), jenis, dan sifat-sifat dari objek jual beli yang sekiranya dapat dijangkau oleh pembeli, berupa barang yang bisa ditakar, ditimbang maupun diukur. Jual beli salam juga dapat berlaku untuk jual beli lintas negara, expor impor dilakukan dengan menyebutkan kualitas, kuantitas, dan sifat-sifat objek jual beli. Penyerahan uang muka dan penyerahan barang disesuaikan dengan kesepakatan bersama dan biasanya dibuat dalam suatu perjanjian. ${ }^{13}$

Berdasarkan berbagai pengertian jual beli di atas, penulis menarik kesimpulan jual beli ialah suatu kegiatan yang dilakukan oleh penjual dan pembeli dalam hal menukarkan harta dengan sesuatu yang memiliki nilai ekonomis, sehingga dapat lebih bermanfaat untuk orang lain. Sedangkan jual beli salam ialah transaksi jual beli yang proses pembayarannya dilaksanakan ketika akad berlangsung dan proses penyerahan barang dilaksanakan di akhir sesuai dengan perjanjian yang telah disepakati oleh penjual dan pembeli.

\section{Analisa Transaksi Akad Bai' As-Salam (Pre-order) dalam Dropship}

Dalam transaksi jual beli online yang menggunakan akad salam adalah praktek jual beli dropshipping. Agar lebih memahami bagaimana mekanisme dan implementasi akad salam dalam jual beli online dan hubungannya dengan akibat hukum apabila ada keterlambatan dalam pelaksanaan akad tersebut, maka dalam hal ini ada baiknya penulis membahas terlebih dahulu tentang praktek jual beli dropshipping. Penulis menggunakan studi kasus toko online vinie.shop.id agar lebih memperjelas gambaran tentang sistem akad salam dalam praktek dropshipping. Dropshipping merupakan suatu usaha penjualan produk yang mana penjual atau dropshipper tidak harus memiliki produk apapun, dapat diartikan sebagai suatu sistem transaksi jual beli dimana pihak dropshipper dapat menentukan harga dari suatu barang yang tidak ia miliki, namun setelah mendapat pesanan barang dari pembeli ia langsung membeli barang dari supplier dan menjualnya pada pembeli sesuai dengan harga yang ia tentukan. ${ }^{14}$ Transaksi jual beli online dengan sistem ini dilakukan dengan cara mengupload foto-foto menarik di media sosial dengan menuliskan kalimat-kalimat yang menarik untuk menarik minat pembeli dengan mencantumkan kontak yang dapat dihubungi pelanggan, apabila berminat pada barang

\footnotetext{
${ }^{11}$ Sayyid Sabiq. (2015). Fiqih Sunnah. Juz. 12. Bandung: Al-Ma'arif, h. 110.

12 Dimyauddin, Djuwaini. (2015). Pengantar Fiqih Muamalah, Yogyakarta: Pustaka Pelajar, h. 129.

${ }^{13}$ M. Ali. Hasan. (2017). Berbagai Macam Transaksi dalam Islam (Figh Muamalah). Jakarta: PT Raja Grafindo Persada, h. 144.

${ }^{14}$ Muflihatul Bariroh. (2013). Transaksi Jual Beli Dropshipping dalam Perspektif Fiqh Muamalah. IAIN Tulungagung, h. 203.
} 
yang ditawarkan dalam foto-foto tersebut, kemudian barang tersebut dipesan dari toko atau supplier apabila pelanggan sudah sepakat dengan kondisi barang dan telah mentransfer uang pembayaran ke rekening bank yang telah ditentukan. Dropsipper tidak menyimpan barang yang akan diperjualbelikan di sebuah gudang, namun hanya bermodalkan foto dan infromasi barang dari toko lain yang berperan sebagai supplier.

Pasal 7 huruf f Undang-Undang Republik Indonesia Nomor 8 Tahun 1999 tentang Perlindungan Konsumen menjelaskan terkait pemberian kompensasi dan ganti kerugian atas barang dan/atau jasa yang diterima atau dimanfaatkan konsumen yang tidak sesuai dengan perjanjian adalah suatu bentuk kewajiban dari seorang pelaku usaha kepada konsumennya untuk menghindari terjadinya ketidaksesuian barang yang diharapkan dengan barang yang di terima konsumen, maka sebaiknya dropshipper memberikan informasi barang yang dijual dengan lengkap dan sebenar-benarnya sebagaimana sesuai dengan aturan yang tertera dalam pasal 9 Undang-Undang Informasi dan Transaksi Elektronik Nomor 19 Tahun 2016 yang mana pelaku usaha yang menawarkan produk dengan sistem elektronik harus menyediakan informasi yang lengkap dan benar terkait syarat kontrak, produsen, dan produk yang ditawarkan.

Jual beli yang dilakukan harus memenuhi rukun dan syarat akad jual beli. Jual beli yang tidak memenuhi rukun dan syarat dianggap tidak sah atau haram. Adapun rukun yang harus dipenuhi yaitu:

1. Para pihak terkait dalam transaksi, yang terdiri dari penjual dan pembeli

2. Objek Transaksi, meliputi:

a. Barang yang diakadkan;

b. Adanya kejelasan. ${ }^{15}$

Syaratnya ialah pihak yang melakukan transaksi baik penjual maupun pembeli saling memahami dan ridho. Sesuai dengan studi kasus yang diteliti, pelayanan toko online menggunakan tulisan dan gambar untuk memudahkan kedua belah pihak dalam melakukan akad tanpa bertatap muka secara langsung. Pihak penjual menampikan gambar barang dagangannya beserta informasi warna, ukuran, dan harga barang tersebut. Ijab qabul akad yang dilakukan secara online dilakukan melalui media chatting atau pesan daring. Penulis berpendapat ijab qabul tersebut tidak ada permasalahan, telah ada kesepakatan dan kerelaan antara penjual dan pembeli, dan telah sesuai dengan rukun akad. Pihak pembeli berkewajiban untuk melakukan pembayaran atas barang yang dibeli dan juga biaya pengiriman barang tersebut. Barang yang diperjual-belikan melalui internet tidak dapat diserahkan secara langsung, sehingga perlu bantuan ekspedisi pengiriman. Biaya pengiriman atas barang tersebut ditanggung oleh pembeli. Dalam hal ini tidak ada unsur paksaan, pembeli bebas memilih barang yang akan dibeli dan juga bebas memilih untuk melanjutkan ataupun membatalkan transaksi dan menggunakan ekspedisi yang diinginkan. ${ }^{16}$

${ }^{15}$ Sahroni Oni. (2016). Fikih Muamalah: Dinamaika Teori Akad dan Implementasinya dalam Ekonomi Syari'ah. Jakarta: Rajawali Press, h.37.

16 A. Rahman I Doi. (2002). Penjelasan Lengkap Hukum-Hukum Allah (Syariah). Jakarta: PT. Raja Grafindo Persada, h. 444. 
Dari penjelasan yang dipaparkan di atas, penulis menganalisis bahwa saat melakukan akad jual beli, pihak yang bersangkutan perlu melihat batasan-batasan dan juga perlu adanya kejelasan dari objek yang akan diperjual-belikan. Kejelasan yang dimaksud ialah barang yang akan diakadkan harus memenuhi 4 (empat) syarat dibawah ini: ${ }^{17}$

1. Lawfulness, artinya barang tersebut harus merupakan barang yang diperbolehkan oleh syariat Islam, harus halal dan benar-benar jauh dari unsur yang diharamkan oleh Allah SWT.

2. Existence, artinya barang yang menjadi objek transaksi tersebut harus nyata, benar, dan bukan tipuan. Barang tersebut harus memiliki wujud yang tetap dan memliki manfaat.

3. Delivery, artinya harus ada kepastian terkait pengiriman dan distribusi barang tersebut. Kesepakatan terkait waktu sangat penting, baik mengenai waktu pentransferan pembayaran oleh pembeli maupun waktu pengiriman barang oleh penjual. Proses pembayaran oleh pembeli dibuktikan dengan bukti transfer berupa gambar struk pengiriman melalui ATM atau m-banking, sedangkan proses pengiriman barang dilakukan oleh ekspedisi dan dibuktikan dengan nomor resi pengiriman yang dapat dilacak keberadaannya oleh pembeli.

4. Precise determination, artinya barang yang diperjual-belikan harus memiliki kualitas dan nilai yang sesuai.

Analisis penulis terkait proses transaksi yang dilakukan toko online dapat dikaitkan dengan 4 (empat) syarat di atas, yaitu:

1. Analisis pemesanan

Barang yang dipesan customer pada toko online vinie.shop.id tidak segera diproses pada saat itu juga, melainkan ditangguhkan waktu penyerahannya. Penjual dan pembeli sepakat untuk menyerahkan barang yang diperjual-belikan dalam waktu yang disepakati bersama. Transaksi ini diperbolehkan dalam Islam dan termasuk dalam kategori jual beli salam. Toko online memberikan keterangan informasi pada setiap gambar yang ada, sehingga pembeli mendapatkan informasi yang jelas mengenai produk yang akan dibeli. Syarat kejelasan jenis, kadar, sifat, dan macamnya telah terpenuhi.

2. Analisis Pembayaran

Harga yang harus dibayar oleh pembeli pada penjual toko online atas barang yang ia beli telah ditentukan pada saat transaksi dilakukan. Proses pembayaran ini telah sesuai dengan syarat yang terkait harga pada jual beli salam, yaitu harga dan pembayaran harus sesuai dan diterima pada saat akad. ${ }^{18}$ Toko online menentukan harga produk yang ia jual, sekaligus menentukan biaya pengiriman disesuaikan dengan jarak kirim dari pihak jasa pengiriman barang atau ekspedisi yang digunakan.

3. Analisis Pengiriman

Toko online berperan sebagai dropshipper, yaitu pihak yang membantu memasarkan produk atau barang yang dimiliki dan dijual oleh supplier, yang menjadi pengirim barang awal sesungguhnya adalah Supplier permasalahn timbul apabila supplier tidak mau

17 Ibid., h. 178-180.

18 Chatibul Umam. (2001). Fiqh Empat Madzhab. Jombang: Darul Ulum Press, h. 237. 
bertanggung jawab atas kecatatan barang yang dikirimkan maka disini yang dirugikan adalah took online dan konsumen. Seharusnya jika ada cacat atau kurang yang dapat mengurangi nilai dari suatu barang, dan cacat atau kurangnya barang tersebut sebelumnya tidak diketahui oleh pembeli, maka pembeli mempunyai hak untuk membatalkan proses jual beli. ${ }^{19}$

\section{Analisis mark up harga}

Menurut Imam Syafi'i, seseorang yang membeli suatu barang berhak dan diperbolehkan untuk menjual kembali barang yang ia beli sesuai dengan harga pokok (harga pembelian). Orang tersebut juga diperbolehkan menjual barang yang ia beli dengan harga yang lebih mahal dari harga pembelian, baik kepada penjualnya sendiri ataupun kepada orang lain, dilakukan sebelum maupun sesudah penyerahan uang. ${ }^{20}$ Artinya pengambilan laba diperbolehkan. Toko online mengaku sebagai pedagang asli kepada pembelinya dan mendapat laba dari mark up harga yang ia lakukan, sehingga sudah seharusnya ia bertanggung jawab ketika terjadi komplain dari pembeli sebanding dengan laba yang ia peroleh. Toko online seharusnya bertindak sebagai perantara yang meneruskan komplain dari pembeli kepada supplier.

\section{Dasar Hukum Akad Bai' As-Salam (Pre-order) dalam Sistem Dropship \\ a. Al-Qur'an}

Akad dalam jual beli salam diperbolehkan berdasarkan dalil-dalil yang terdapat dalam Alquran. Islam merupakan agama mengatur terkait semua tingkah laku manusia, mulai dari keimanan, tauhid, ibadah, samapai masalah ekonomi. Meskipun ekonomi ini bukan merupakan tujuan utama dalam risalah Islam. Tetapi masalah ekonomi merupakan suatu hal yang perlu diperhatikan, karena merupakan salah satu faktor pendukung tercapainya suatu masyarakat yang beriman dan bertauhid kepada Allah SWT. Firman Allah SWT QS Al-Baqarah ayat 282 menjadi bukti bahwa masalah ekonomi diatur dalam Islam. ${ }^{21}$ Firman tersebut menekankan tentang perilaku muamalah.

\footnotetext{
${ }^{19}$ Fadhli Bahri. (2011). Ensiklopedi Muslim. Jakarta: Darul Falah, h. 495.

${ }^{20}$ Abdullah Zaki Alkaf. (2004). Figh Empat Madzhab. Bandung: Hasyimi, h. 239.

${ }^{21}$ QS Al-Baqarah ayat 282: "Hai orang-orang yang beriman, apabila kamu bermu'amalah tidak secara tunai untuk waktu yang ditentukan, hendaklah kamu menuliskannya. Dan hendaklah seorang penulis di antara kamu menuliskannya dengan benar. Dan janganlah penulis enggan menuliskannya sebagaimana Allah mengajarkannya, maka hendaklah ia menulis, dan hendaklah orang yang berhutang itu mengimlakkan (apa yang akan ditulis itu), dan hendaklah ia bertakwa kepada Allah, dan janganlah ia mengurangi sedikitpun daripada hutangnya. Jika yang berhutang itu orang yang lemah akalnya atau lemah (keadaannya) atau dia sendiri tidak mampu mengimlakkan, maka hendaklah walinya mengimlakkan dengan jujur. Dan persaksikanlah dengan dua orang saksi dari orang-orang lelaki (di antaramu). Jika tak ada dua oang lelaki, maka (boleh) seorang lelaki dan dua orang perempuan dari saksi-saksi yang kamu ridhai, supaya jika seorang lupa maka yang seorang mengingatkannya. Janganlah saksisaksi itu enggan (memberi keterangan) apabila mereka dipanggil; dan janganlah kamu jemu menulis hutang itu, baik kecil maupun besar sampai batas waktu membayarnya. Yang demikian itu, lebih adil di sisi Allah dan lebih menguatkan persaksian dan lebih dekat kepada tidak (menimbulkan) keraguanmu. (Tulislah mu'amalahmu itu), kecuali jika mu'amalah itu perdagangan tunai yang kamu jalankan di antara kamu, maka tidak ada dosa bagi kamu, (jika) kam tidak menulisnya. Dan persaksikanlah apabila kamu berjual beli; dan janganlah penulis
} 
Muamalah yang dilakukan dalam hutang piutang maupun dalam jual beli dengan pembayaran tidak secara tunai dianjurkan untuk ditulis. Jual beli salam yang merupakan jual beli pesanan yang pembayarannya dilakukan dimuka, baik tunai ataupun tidak, diharuskan untuk melakukan pencatatan atau penulisan dalam transaksinya. Isi dan maksud dari dalil di atas mewajibkan pencatatan atau penulisan dalam setiap dilakukannya transaksi muamalah.

\section{b. Hadist}

Jual beli juga dijelaskan di dalam ketetapan (hadis) Nabi Muhammad SAW. Rasulullah bersabada dalam hadis-hadis berikut:

"Janganlah dua orang yang jual beli berpisah, sebelum saling meridhoi" (H.R. Abu Dawud dan Tirmidzi).22

"Siapa saja yang melakukan jual beli salam (salaf), maka lakukanlah dalam ukuran (takaran) tertentu, timbangan tertentu dan waktu tertentu". (HR. Bukhari-Muslim)

Imam Bukhari dari Ibnu Abbas menerangkan hadis Nabi Muhammad SAW yang berkaitan dengan hukum jual beli salam, yaitu Telah menceritakan kepada kami Abu Nu'aim dan Sufyan, dari Ibnu Abi Najih, dari 'Abdullah bin Katsir, dari Abu Al Minhal, dari Ibnu 'Abbas radliallahu 'anhuma berkata: Ketika Rasulullah SAW tiba di Madinah, orang-orang mempraktekkan jual bebuah-buahan dengan sistem salaf, yaitu membayar dimuka dan diterima barangnya setelah kurun waktu dua atau tiga tahun. Maka Rasulullah bersabda:

"Lakukanlah jual beli salaf pada buah-buahan dengan takaran sampai waktu yang diketahui (pasti)".

Selain itu, dalam hadis yang diriwayatkan oleh Imam Bukhari dari 'Abdurrahman bin Abzaa dan 'Abdullah bin Abi Aufaa, yaitu Telah menceritakan kepada kami Muhammad bin Muqatil telah mengabarkan kepada kami 'Abdullah telah mengabarkan kepada kami Sufyan dari Sulaiman Asy- Syaibaniy dari Muhammad bin Abi Al Mujalid berkata; 'Abdullah bin Syaddad dan Abu Burdah mengutusku untuk menemui 'Abdurrahman bin Abzaa dan 'Abdullah bin Abi Aufaa lalu aku menanyakan keduanya tentang jual beli As- Salaf. Keduanya berkata:

"Kami pernah mendapatkan ghanimah (harta rampasan perang) bersama Rasulullah shallallahu 'alaihi wasallam lalu datang kepada kami bangsa blasteran dari penduduk negeri Syam, kemudian kami berjual beli dengan cara As-Salaf pada biji gandum, padi dan kismis untuk jangka waktu tertentu. Dia berkata; Aku tanyakan: 'Apakah saat itu mereka memiliki pertanian atau tidak?' Keduanya menjawab: 'Kami tidak pernah menanyakan hal itu kepada mereka'".

Sabda Rasulullah yang diterangkan di atas muncul ketika beliau pertama kali hijrah ke Madinah dan mendapati penduduk Madinah sedang melakukan transaksi jual beli salam. Sehingga beliau memperbolehkan jual beli salam dengan syarat akad yang digunakan dalam transaksi tersebut jelas, ciri-ciri barang yang dipesan jelas, dan adanya ketentuan waktu. ${ }^{23}$

dan saksi saling sulit menyulitkan. Jika kamu lakukan (yang demikian), maka sesungguhnya hal itu adalah suatu kefasikan pada dirimu. Dan bertakwalah kepada Allah; Allah mengajarmu; dan Allah maha mengetahui segala sesuatu."

22 A. Hasan. (2018). Bulughul Maram. Bandung: CV. Diponegoro, h. 406.

${ }^{23}$ Nasroen Haroen. (2017). Fiqih Muamalah. Jakarta: Gaya Media Pratama, h. 148 
Jual beli salam hukumnya dibolehkan selama ukuran, timbangan, dan waktunya ditentukan dengan jelas. Dasar hukum jual beli salam sudah sesuai dengan kaidah dan tuntutan syariat islam. Jual beli dalam prakteknya juga tidak menyalahi qiyas yang membolehkan melakukan penangguhan pada penyerahan barang, seperti halnya dibolehkannya penangguhan dalam proses pembayaran. ${ }^{24}$

\section{c. Ijma'}

Ijma' ulama juga merupakan dasar hukum bai' as-salam selain ayat al-qur'an dan hadis. Ibnu Mundzir dan ulama lainnya meriwayatkan adanya ijma' atas dibolehkannya transaksi jual beli salam. Kebutuhan manusia untuk melakukan transaksi mendorong dibolehkannya jual beli salam. Dalam terjadinya transaksi, satu pihak ingin mendapat pembayaran yang cepat, sementara pihak yang lain ingin mendapat barang yang pasti dan jelas. Transaksi salam juga memberikan kemudahan bagi yang berkepentingan, contohnya bagi pemilik lahan pertanian, perkebunan ataupun perniagaan yang terkadang membutuhkan modal untuk mengelola usaha mereka dari awal hingga siap dipasarkan. Ketentuan dalam ijma' ulama dengan jelas memberikan legalisasi praktik pembiayaan atau jual beli salam. ${ }^{25}$ Selain itu, jual beli salam juga kemudahan bagi manusia yang dalam upaya merealisasikan kemaslahatan perekonomian.

\section{Syarat Jual Beli As-Salam}

Syarat-syarat jual beli salam yang harus dipenuhi yaitu sebagai berikut:

\section{a. Syarat Orang yang Berakad (Al-Aqid)}

Ulama' Malikiyah dan Hanafiyah mensyaratkan orang yang melakukan akad (yang disebut aqid) harus berakal, sudah mumayyiz, minimal berusia 7 (tujuh) tahun yang mana pembicaraan dan jawaban yang dilontarkannya dapat dipahami. Oleh sebab itu, orang gila, orang bodoh, dan anak kecil tidak diperbolehkan menjual harta sekalipun kepemilikan harta tersebut atas namanya. ${ }^{26}$ Allah SWT berfirman dalam surat An-Nisa' ayat 5, yang artinya:

"Dan janganlah kamu serahkan kepada orang-orang yang belum sempurna akalnya, harta (mereka yang ada dalam kekuasaanmu) yang dijadikan Allah sebagai pokok kehidupan. Berilah mereka belanja dan pakaian (dari hasil harta itu) dan ucapkanlah kepada mereka perkataan yang baik".

Syarat aqid menurut Syafi'iyah dan Hanabilah harus dilakukan oleh orang yang balig (terkena perintah syara'), berakal, serta telah mampu memelihara agama dan hartanya. Hanabilah membolehkan anak kecil melakukan pembelian barang yang sederhana atas ijin dari wali anak tersebut. ${ }^{27}$ Pertimbangan kecakapan yang dimiliki oleh orang yang telah balig bukan dilihat dari bilangan umur, tetapi dititikberatkan pada akal yang sempurna. Kualitas kemampuan berpikir juga menjadi pengaruh yang signifikan atas pertimbangan cakap tidaknya seseorang untuk melakukan perbuatan hukum atau

\footnotetext{
24 Burhanuddin. (2019). Hukum Kontrak Syariah. Yogyakarta: BPFE, h. 213.

25 Rozalinda. Op.Cit, h. 131.

${ }^{26}$ Hendi Suhendi. (2019). Fiqih Muamalah, Jakarta: PT Grafindo Persada, h. 74

27 Rahmat Syafi'i. (2016). Fiqih Muamalah, Bandung: Pustaka Setia, h. 54
} 
hal-hal lain yang dapat menimbulkan tanggungjawab dikemudian hari atas perbuatan yang dilakukan. ${ }^{28}$

\section{b. Syarat tentang Waktu dan Tempat Penyerahan Barang}

Waktu penyerahan barang dapat dilakukan dengan menentukan tanggal dan hari yang disepakati oleh kedua belah pihak. Namun, terdapat jenis barang tertentu yang waktu penyerahannya tidak dapat ditentukan demikian. ${ }^{29}$ Ulama Hanafiyah dan Hanabilah memberi syarat tenggang waktu penyerahan barang maksimal satu bulan. Sedangkan ulama Malikiyah memberi tenggang waktu maksimal setengah bulan.

Pihak yang melakukan transaksi harus menyepakati tempat untuk dilakukannya penyerahan barang yang dipesan. Penentuan tempat penyerahan barang diperlukan bagi transaksi jual beli barang yang memerlukan biaya pengiriman atau apabila tempata penyerahan barang pesanan tidak layak, seperti di tengah gurun. Namun, penentuan tempat penyerahan barang tidak diperlukan jika transaksi jual beli tidak memerlukan biaya pengiriman dan tempat terjadinya transaksi jual beli layak untuk dijadikan tempat penyerahan barang. ${ }^{30}$

Apabila tempat serah terima barang tidak ditentukan oleh kedua belah pihak yang saling berakad, jual beli salam tersebut tetap dianggap sah, dan tempat serah terima barang dapat ditentukan dilain waktu. Tidak ada ketentuan yang mengatur terkait hal tersebut. Apabila penyerahan barang merupakan syarat sah jual beli salam, maka Rasulullah akan menyebutkannya seperti halnya beliau menyebutkan tentang takaran, timbangan dan waktu. Waktu dan tempat penyerahan barang dalam akad salam tergantung pada kesepakatan pihak yang bertransaksi untuk menghindari perselisihan dan untuk memberikan rasa aman.

Penjual atau produsen wajib menyerahkan barang apabila tenggang waktu yang telah disepakati sudah jatuh tempo. Jika pembeli atau konsumen tidak menerima barang hingga jatuh tempo waktu penyerahan barang, maka pihak pembeli atau konsumen tersebut bersabar hingga barang yang ia pesan tersedia, atau pihak pembeli dapat membatalkan transaksinya dan meminta kembali uangnya (refund). Karena jika transaksi batal, maka penjual harus mengembalikan pembayaran sesuai dengan harga yang dibayar pembeli. Dikembalikan, dan apabila tuang pembayaran hilang, penjual juga harus menggantinya.

Pembeli telah menerima barang yang ia pesan dan terdapat cacat pada barang tersebut ataupun terdapat ketidaksesuaian barang dengan informasi kualitas, kuantitas, sifat, atau ciri-ciri yang diberikan oleh penjual, maka pembeli boleh meminta ganti kerugian atau memutuskan apakah ia akan menerima cacat/ketidaksesuaian barang, sekalipun dalam jual beli salam tidak ada hak khiyar. Dalam fiqih Islam juga menerangkan, apabila pada barang yang dibeli terdapat kerusakan, cacat, dan

\footnotetext{
${ }^{28}$ Ahmad Azhar Basyir. (2014). Asas-Asas Hukum Muamalat (Hukum Perdata Islam). Yogyakarta: UII Press, h. 31.

${ }^{29}$ Adiwarman Aswar Karim. (2017). Ekonomi Islam Suatu Kajian Kontemporer. Jakarta: Gemas Insani Press, h. 93.

${ }^{30}$ Ashabul Fadhli. (2016). Tinjauan Hukum Islam terhadap Penerapan Akad As-Salam dalam Transaksi E-Commerce. Jurnal Pemikiran Hukum Islam, Vol, XV, No. 1, h. 13.
} 
ketidaksesuaian dengan apa yang dipesan, maka barang tersebut dapat dikembalikan kepada penjualnya. Ketentuan ini bertujuan untuk menjamin hak-hak pembeli atau konsumen agar mendapatkan barang sesuai dengan yang dipesan.

\section{c. Syarat Ijab dan Qabul (Sighat) ${ }^{31}$}

Sighat merupakan pernyataan ijab dan qabul. Ijab adalah pernyataan pertama dari seseorang yang melakukan transaksi, yang menunjukkan keinginannya untuk melakukan transaksi. Qabul adalah pernyataan terakhir dari pihak kedua yang menunjukkan kerelaan untuk menerima pernyataan pihak pertama. Unsur penting dalam jual beli salam sama halnya dengan unsur penting jual beli lainnya, yaitu kerelaan dari kedua belah pihak, sama halnya dengan jual beli lainnya. Sesuai dengan apa yang ditentukan oleh Allah SWT dalam surat An-Nisa' ayat 29 yang artinya sebagai berikut:

"Hai orang-orang yang beriman, janganlah kamu saling memakan harta sesama dengan jalan yang batil, kecuali dengan jalan perniagaan yang berlaku dengan suka sama suka diantara kamu". adalah: ${ }^{32}$

Syarat-syarat ijab qabul (sighat) yang harus dipenuhi dalam jual beli salam

1) Ijab qabul harus mengandung tujuan yang jelas dan terdapat kesesuaian didalamnya, sehingga para pihak akan mudah untuk memahaminya.

2) Ijab qabul harus berhubungan dalam satu majlis. Jika para pihak hadir untuk bertemu langsung dalam satu tempat kemudian melaksanakan transaksi, maka tempat bertemunya para pihak disebut majlis akad. Namun, apabila para pihak tidak berada dalam satu tempat atau berjauhan, maka majlis akad ialah tempat tempat terjadinya qabul. Pernyataan ijab qabul bisa dilakukan dengan berbagai cara, baik secara lisan, tulisan, surat menyurat, ataupun isyarat yang jelas yang dapat memberi pengertian tentang adanya ijab qabul. dan Perbuatan yang telah menjadi kebiasaan dalam ijab qabul juga dapat menjadi pernyataan ijab qabul.

3) Memakai kata as-salam atau as-salaf. Pada mulanya jika yang dipakai adalah kata jual beli (al-bai') maka tidak sah, dengan alasan karena jual beli pesanan termasuk dalam jual beli yang secara qiyas tidak diperbolehkan. Namun, pelarangan ini telah dihapuskan dengan mempertimbangkan kebutuhan masyarakat terhadap kontrak salam. Para ulama berpendapat, pembatasan terhadap penggunaan kata diperlukan sesuai dengan yang diajarkan dalam syara'. Syara' hanya membolehkan penggunaan kata salam dan salaf dalam akad. Tetapi, pendapat lain ada yang membolehkan penggunaan membolehkan penggunaan kata jual beli (al-bai') dan penggunaan kata tersebut dianggap sah dalam transaksi.

Nurul Huda dan Muhammad berpendapat bahwa hal-hal lain yang berkaitan dengan transaksi salam dapat dilihat di dalam ketentuan Pembiayaan Bai as-Salam sesuaidengan Fatwa No.05/1 DSN-MUI/IV/2000 tanggal 1 April 2000 yang secara terperinci mengatur mekanisme salam yang diharuskan berdasar pada unsur kerelaan antara para pihak. Rukun dan syarat jual beli harus dipenuhi agar transaksi jual beli salam menjadi sah. Dalam jual beli salam, barang yang diperjualbelikan tidak harus diserahkan ketika akad, dan tidak ada keharusan hadirnya penjual pada waktu transaksi.

\footnotetext{
${ }^{31}$ Uswah Hasanah. (2018). Bay' Al-Salam dan Bay' Al-Istisna'. Jurnal Agama dan Pendidikan Islam, h. 164.

${ }^{32}$ Saprida. (2016). Akad Salam dalam Transaksi Jual Beli. Jurnal Ilmu Syariah, Vol. 4, No. 1, h. 125.
} 
Oleh sebab itu, penulis menyimpulkan bahwa segala bentuk transaksi yang dilakukan atas dasar jual beli salam diharuskan memenuhi segala persyaratan yang dianjurkan agar memiliki hasil yang bermanfaat untuk orang lain.

\section{Rukun Jual Beli As-Salam}

Ulama Hanafiyah berpendapat bahwa rukun jual beli salam hanya terdiri dari ijab (pernyataan dari pihak pemesan atau konsumen untuk memesan barang) dan qabul (pernyataan dari pihak penjual atau produsen untuk mengerjakan barang pesanan). Lafadz yang digunakan dalam jual beli pesanan menurut ulama Syafi'iyah adalah assalam dan as-salaf. Penggunaan dua kata as-salam dan as-salaf dengan alasan hanya didasarkan menurut kaidah umum (analogi) jual beli tersebut tidak dibolehkan, karena barang yang ditransaksikan tidak terlihat ketika akad. Namun, syara' memperbolehkan jual beli ini dengan syarat harus menggunakan lafadz as-salam dan as-salaf. Sedangkan menurut ulama Malikiyah, Hanafiyah, dan Hanabilah, lafadz yang digunakan adalah assalam, as-salaf, atau al-bai' (jual beli).

Rukun jual beli salam menurut jumhur ulama, dalam hal ini selain Hanafiah, terdiri atas:

a. Al-Aqid

Al-Aqid merupakan orang yang melakukan akad. Pihak penjual dalam perjanjian salam disebut dengan al-muslam ilaih yang berarti orang yang diserahi. Pihak pembeli disebut dengan al-muslam atau pemilik as-salam yang berarti orang yang menyerahkan. Aqid dalam jual beli salam sangatlah penting, karena suatu perbuatan tidak dapat dikatakan sebagai akad apabila tidak ada aqid. Tanpa aqid juga tidak akan terjadi ijab qabul.

b. Objek Jual Beli Salam

Objek yang menjadi jual beli salam yaitu harga dan barang yang dipesan. Barang yang menjadi objek dalam jual beli salam disebut al-Muslam Fih. Barang sebagai objek jual beli salam haruslah jelas harga, informasi mengenai barang tersebut, ciri-ciri dan waktu penyerahannya.

c. Sighat (Ijab dan Qabul)

Ijab dan qabul harus sesuai dengan ketentuan syari'at, yang dapat berpengaruh pada objek perikatan. Sesusai kehendak syari'at dalam hal ini berarti bahwa seluruh perikatan yang dilakukan oleh para pihak tidak diperbolehkan apabila bertentangan atau tidak sejalan dengan ketentuan syara'. Contoh yang tidak sesuai dengan ketentuan syari'at antara lain, penipuan, transaksi riba, atau perampokan terhadap kekayaan orang lain. Sedangkan yang dimaksud dengan berpengaruh pada objek perikatan adalah terjadinya perpindahan kepemilikan objek jual beli dari satu pihak yang melakukan ijab kepada pihak lain menyatakan qabul.

Seperti yang telah diketahui dalam hukum Islam, keterlambatan pengiriman barang yang terjadi dalam jual beli akad as-salam diperbolehkan karena terdapat pendapat ulama mengenai tenggang waktu dalam penyerahan barang yang menjadi objek jual beli tersebut. Waktu penyerahan dapat saja ditentukan tanggal dan harinya, meskipun tidak semua jenis barang yang menjadi objek jual beli dapat ditentukan 
demikian. Tenggang waktu yang ditentukan oleh ulama Hanafiyah dan Hanabilah adalah satu bulan. Sedangkan ulama Malikiyah menentukan tenggang waktunya paling lama adalah setengah bulan. Namun dalam hukum Islam juga dijelaskan sebab batalnya atau berakhirnya suatu perjanjian jual beli akad as-salam dikarenakan:

1. Barang yang dipesan tidak ada wujudnya sampai pada tenggang waktu yang telah ditentukan sebagaimana mestinya kesepakatan diiawal terjadinya jual beli;

2. Terdapat cacat atau ketidaksesuaian pada barang yang diterima pembeli sebagaimana kesepakatan bersama para pihak saat akad;

3. Barang yang diterima pembeli memiliki kualitas rendah, sehingga pembeli menolak atau membatalkan akadnya;

4. Kualitasnya barang yang diterima pembeli tidak sesuai dengan akad awal, tetapi pembeli tetap menerimanya;

5. Barang telah diterima oleh pembeli. ${ }^{33}$

Ketika keterlambatan kita kaitkan dengan kondisi pada saat pandemi Covid-19 maka syarat pada awal akad as-salam transaksi harus diperhatikan tentang kesepakatan dan toleransi waktu serta proses penyerahan barang yang mana harus terdapat kejelasan yang akan memberikan rasa aman dan menjaga agar tidak ada kesalah pahaman para pihak, sehingga diharapkan dapat memberikan kerelaan dan keridhoan dalam bertransakasi, sehingga akan mengakibatkan kebaikan bagi para pihak dan juga ridho Allah SWT. Dalam hal jual beli akad as-salam dinyatakan tidak sah jika diawal telah dicantumkan tentang adanya keterlambatan pengiriman barang walaupun alasan tersebut karena adanya pandemi Covid-19, dengan itu dinyatakan sebagai berakhirnya jual beli akad as-salam. Apabila jangka waktu penyerahan barang sudah ditentukan namun mengalami keterlambatan, maka jual beli akad as-salam ini mengandung unsur gharar, yauti tidak adanya suatu kepastian, sehingga berakibat munculnya resiko penipuan yang dapat menimbulkan perselisihan. Jual beli yang di dalamnya mengandung unsur gharar akan merugikan salah satu pihak dan menghilangkan unsur keridhaan yang menjadi dasar dalam setiap jual beli, maka dari itu penentuan kesepakatan jangka waktu penyerahan barang walaupun adanya keterlambatan barang merupakan hal yang sangat penting. Bukan hanya didalam hukum Islam saja jual beli tersebut batal melainkan dalam jual beli biasa yang mana dijelaskan oleh Subekti adalah wanprestasi.

33 Aris Munandar. (2017). Keterlambatan Penyerahan Barang dalam Jual Beli Perabotan dengan Akad Isitisna' Menurut Tinjauan Hukum Islam. Jurista, Vol. 6, No. 1, h. 25. 


\section{PENUTUP}

Mewabahnya Covid-19 di Indonesia antara lain berdampak dalam bidang jual beli (pre order). Implikasi hukum transaksi atau jual beli online dengan pesanan (pre order) atau akad as-salam, dalam masa wabah pandemi Covid-19 mengakibatkan permasalahan seperti keterlambatan pengiriman barang karena terjadi penutupan kegiatan arus lintas barang. Jual beli as-salam memiliki pengertian sebagai jual beli yang mana pembeli membeli barang yang memiliki kriteria tertentu dengan cara melakukan pembayaran terlebih dahulu dan barang akan diserahkan dikemudian waktu tertentu. Ketika kita melihat model transaksi dalam kasus di atas berkaitan dengan beberapa pihak yakni pabrik, pemilik toko online, pihak pengiriman barang dan pembeli barang. Supaya berdampak baik dan terhindar dari unsur gharar yang dapat merugikan pihak pembeli dan menghadirkan unsur keridhaan yang merupakan dasar dalam setiap jual beli, maka dibutuhkan kejujuran dan niat baik para pihak serta kesepakatan jangka waktu penyerahan barang.

Dalam masa wabah Covid-19 saat ini seharusnya pihak penjual melakukan antisipasi dengan pemberitahuan sebelumnya kepada pihak pembeli jika terjadi keterlambatan pengiriman barang sehingga tidak memberikan celah pada pembatalan jual beli, juga tidak akan merugikan pihak pembeli yang sedang menunggu datangnya barang yang telah dipesan, serta supaya terhindar dari unsur gharar.

\section{DAFTAR PUSTAKA}

\section{Buku:}

A. Hasan. (2018). Bulughul Maram, Bandung: CV. Diponegoro.

Adiwarman Aswar Karim. (2017). Ekonomi Islam Suatu Kajian Kontemporer, Jakarta: Gemas Insani Press.

Ahmad Azhar Basyir. (2014). Asas-Asas Hukum Muamalat (Hukum Perdata Islam), Yogyakarta: UII Press.

Burhanuddin. (2019). Hukum Kontrak Syariah, Yogyakarta: BPFE.

Chairuman Pasaribu dan Suhrawardi K. Lubis. (2016). Hukum Perjanjian dalam Islam, Jakarta: Sinar Grafika.

Dimyauddin, Djuwaini. (2015). Pengantar Fiqih Muamalah. Yogyakarta: Pustaka Pelajar. Ghufron Mas'adi. (2018). Fiqih Muamalah Kontekstual. Jakarta: Raja Grafindo Persada. Hendi Suhendi. (2019). Fiqih Muamalah. Jakarta: PT Grafindo Persada.

M. Ali. Hasan. (2017). Berbagai Macam Transaksi dalam Islam (Fiqh Muamalah). Jakarta: PT Raja Grafindo Persada.

Mardani. (2017). Fiqih Ekonomi Syariah: Fiqih Muamalah. Jakarta: Kencana Prenada Media Group.

Muhammad. (2018). Model-Model Akad Pembiayaan di Bank Syariah (Panduan Teknis Pembuatan Akad atau Perjanjian Pembiayaan pada Bank Syariah. Yogyakarta: UII Press.

Nasroen Haroen. (2017). Fiqih Muamalah. Jakarta: Gaya Media Pratama.

Rahmat Syafi'i. (2016). Fiqih Muamalah. Bandung: Pustaka Setia.

Rozalinda. (2016). Fiqih Ekonomi Syariah, Jakarta: Raja Grapindo Persada. 
Sayyid Sabiq. (2015). Fiqih Sunnah. Juz. 12. Bandung: Al-Ma'arif.

Wahbah al-Zuhaili. (2015). Fiqih Islam wa Adillatuhu, Jilid V, Jakarta: Gema Insan.

Wahbah al-Zuhairi. (2016). al-Figh al-Islami wa Adillatuhu. Juz IV, Damaskus: Darul Fikr.

\section{Jurnal:}

Abdul Haris Simal. (2019). Pelaksanaan Jual Beli Dengan Menggunakan Akad As-Salam Ditinjau Dari Prinsip Tabadul Al-Manafi, Jurnal Cahkim, Vol. XV, No. 1.

Ashabul Fadhli. (2016). Tinjauan Hukum Islam Terhadap Penerapan Akad As-Salam dalam Transaksi E-Commerce, Jurnal Pemikiran Hukum Islam, Vol, XV, No. 1.

Aris Munandar. (2017). Keterlambatan Penyerahan Barang dalam Jual Beli Perabotan dengan Akad Isitisna' Menurut Tinjauan Hukum Islam, Jurista, Vol. 6, No. 1.

Chairul Iksan Burhanuddin, dkk. (2020). Ancaman Krisis Ekonomi Global dari Dampak Penyebaran Virus Corona (Covid-19), Jurnal Akuntansi, Vol. 17, Nomor 1.

MLE Parwanto. (2020). Virus Corona (2019-NCOV) Penyebab COVID-19, Jurnal Biomedika dan Kesehatan, Vol. 3, Nomor 1.

Saprida. (2016). Akad Salam Dalam Transaksi Jual Beli, Jurnal Ilmu Syariah, Vol. 4, No. 1.

Silpa Hanoatubun. (2020). Dampak Covid-19 terhadap Perekonomian Indonesia, Journal of Education, Psychology, and Counseling, Vol. 2, Nomor 1.

Shobirin. (2015). Jual Beli Dalam Pandangan Islam, Jurnal Bisnis dan Manajemen Islam, Vol. 3, No. 2.

Yunus, Fahmi, dan Gusti. (2018). Tinjauan Fikih Muamalah Terhadap Akad Jual Beli Dalam Transaksi Online Pada Aplikasi Go-Food, Jurnal Ekonomi dan Keuangan Syariah, Vol. 2, No. 1.

Uswah Hasanah. (2018). Bay' Al-Salam dan Bai' Al-Istisna', Jurnal Agama dan Pendidikan Islam.

\section{Internet:}

Worldometer.

Covid-19

Coronavirus

Pandemic.

https://www.worldometers.info/coronavirus/ 